\title{
EFEKTIVITAS EKSTRAK BAWANG PUTIH (Allium sativum L.) DENGAN DAUN BAJAKAH (Uncaria acida Roxb.) SEBAGAI LARVASIDA VEKTOR DENGUE Aedes aegypti
}

\author{
Fitra Akbar Mulyono ${ }^{1 *}$, Iqlila Romaidha ${ }^{1}$, Nur Aini Hidayah Khasanah¹, Febri Nur \\ Ngazizah ${ }^{1}$ \\ 'D-III Analis Kesehatan, Stikes Borneo Cendekia Medika, Kalimantan Tengah, Indonesia \\ e-mail : fitraakbaranalis@gmail.com
}

\begin{abstract}
Absract
Dengue fever is a disease caused by the dengue virus carried by the A. aegypti mosquito. Making natural larvicides from plants such as Alium sativum L. and Uncaria acida Roxb. are indispensable. This study aims to make natural larvicides from A. sativum and U. acida. This study is an experimental study using a Completely Randomized Design (CRD) to see the effectiveness of the extract $A$. sativum with $U$. acida as larvicide of the mosquito $A$. aegypti. This study used 20 mosquito larvae for each concentration and repeated 4 times. The results showed that the larvicide of $A$. sativum at the highest concentration reached $100 \%$ mortality, while the larvicide of $U$. acida at the highest concentration reaching $80 \%$ mosquito larvae death A. aegypti. Analysis of research data was processed using SPSS version 20. One Way Anova analysis of $A$. sativum extract was sig 0.049 and $U$. acida extract was sig 0.245 . In the extract of $A$. sativum there was a significant difference in the mortality of mosquito larvae at each concentration, while in the extract of $U$. acida there was no significant difference in the mortality of mosquito larvae at each concentration. T-test analysis of the extracts of $A$. sativum and $U$. acida was sig 0.80 , so there was no difference in effectiveness between the two larvicidal extracts. It can be concluded that the larvicidal research results of $A$. sativum extract and $U$. acida extract were equally effective on $A$. aegypti larvae.
\end{abstract}

Keywords : A. aegypti, A. sativum, Larvicide, One Way Anova, U. acida.

\begin{abstract}
Abstrak
Demam berdarah adalah penyakit yang disebabkan virus dengue yang dibawa nyamuk Aedes aegypti. Pembuatan Larvasida alami dari tumbuhan seperti Alium sativum L. dan Uncaria acida Roxb sangat diperlukan. Penelitian bertujuan untuk membuat larvasida alami dari Aedes. sativum dan $U$. acida. Penelitian ini merupakan penelitian eksperimental menggunakan Rancangan Acak Lengkap (RAL) untuk melihat efektivitas dari ekstrak $A$. sativum dengan $U$. acida sebagai larvasida nyamuk Aedes. aegypti. Dalam penelitian menggunakan larva nyamuk sebanyak 20 ekor untuk setiap konsentrasi dan diulang sebanyak 4 kali pengulangan. Hasil penelitian menunjukkan larvasida $A$. sativum pada konsentrasi tertinggi mencapai $100 \%$ kematian sedangkan larvasida U. acida pada konsentrasi tertinggi mencapai $80 \%$ kematian larva nyamuk Aedes aegypti. Analisa data menggunakan SPSS versi 20. Analisa One Way Anova ekstrak A. sativum bernilai sig 0.049 dan ekstrak U. acida bernilai sig 0.245. Pada ekstrak A sativum terdapat perbedaan signifikan kematian larva nyamuk pada setiap konsentrasi sedangkan ekstrak $U$. acida tidak terdapat perbedaan signifikan kematian larva nyamuk pada setiap pemberian konsentrasi. Analisa T-tes ekstrak A. sativum dan U. acida bernilai sig 0.80 maka tidak ada perbedaan efektivitas di kedua ekstrak larvasida. disimpulkan hasil penelitian larvasida ekstrak A. sativum dan ekstrak U. acida sama-sama efektif pada larva Aedes aegypti.
\end{abstract}

Kata kunci : Aedes aegypti, A. sativum, Larvasida, One Way Anova, U. acida. 
Demam Berdarah Dengue merupakan penyakit yang disebabkan oleh suatu virus bernama Virus Dengue yang ditularkan dari gigitan nyamuk Aedes aegypti. Penyakit Demam Berdarah Dengue telah menginfeksi setidaknya dua juta orang dan menyebabkan kematian hingga 10.000 orang setiap tahun. Hingga saat ini, demam berdarah dengue masih menjadi salah satu penyakit under reported (Aryati, 2017).

Menurut data WHO, Asia merupakan negara yang memiliki angka demam berdarah tertinggi dan menyumbangkan hingga 75\% demam berdarah di dunia dari tahun 2004 dan 2010. Indonesia menempati peringkat ke dua kasus DBD tertinggi setelah Brazil (Indrayani, 2018). Berdasarkan data Kementerian Kesehatan RI pada tahun 2018 hingga tahun 2019 korban tertinggi penyakit DBD berada pada provinsi Jawa Timur, dengan kasus mencapai 700 orang. Selanjutnya pada provinsi Jawa Tengah dengan kasus DBD hingga 512 orang dan pada ada Jawa Barat kasus DBD sebesar 401 orang. Pada pulau Kalimantan, tertinggi pada Provinsi Kalimantan Barat disusul dengan Provinsi Kalimantan Tengah (Kemenkes RI, 2019).

Salah satu kabupaten dengan angka kasus tertinggi pada Provinsi Kalimantan Tengah yaitu Kotawaringin Barat. Menurut Dinas Kesehatan Kotawaringin Barat (2020), dari bulan Januari sampai bulan Juni kasus demam berdarah mencapai 76 orang.

Pengendalian utama penyakit demam berdarah yaitu dengan meningkatkan sanitasi lingkungan dan penggunaan larvasida dan insektisida untuk mengatasi perkembangan vektor demam berdarah pada tahapan hidup yang berbeda. Salah satu upaya pemerintah saat ini yaitu pemberian larvasida sintetis. Larvasida yang digunakan untuk pengendalian larva A. aegypti adalah golongan organofosfat yaitu abate dengan bahan aktif temephos. A. aegypti memiliki adaptasi yang cukup tinggi dalam mempertahankan hidupnya. Nyamuk $A$. aegypti dapat hidup dan bertelur dalam habitat yang kecil, sumber nutrisi terbatas, suhu yang kurang optimum dan cengkaman dari luar (Dinata, 2016). 
Larvasida alami dapat digunakan untuk mengatasi permasalahan vektor nyamuk $A$. aegypti pada stadium larva dengan mengurangi kerugian pada kesehatan dan lingkungan (Sembel, 2015). Uncaria acida Roxb. dan Alium sativum L. memiliki senyawa alami yang dapat digunakan sebagai larvasida alami. Terdapat banyak senyawa yang dimiliki oleh tanaman yang dapat memberikan manfaat sebagai larvasida hama alami. Senyawa alami yang dihasilkan oleh tanaman yang dapat digunakan untuk membunuh larva nyamuk antara lain senyawa saponin, alkoloid, alliin, flovoid dan tektoquinon dapat digunakan sebagai larvasida alami (Saputera, 2018). Salah satu kandungan yang dimiliki $A$. sativum seperti alisin merupakan senyawa organosulfur yang biasa digunakan dalam pembuatan larvasida (Moulia dkk., 2018).

Dari uraian di atas, mendorong peneliti untuk mengadakan penelitian tentang perbedaan efektivitas ekstrak $A$. sativum dan $U$. acida sebagai larvasida alami pada tahapan larva A. aegypti. Penggunaan bahan larvasida yang berbeda bertujuan untuk mengetahui larvasida alami mana yang lebih efektif dalam membunuh larva nyamuk $A$. aegypti. Pada penelitian ini, menggunakan ekstrak bawang putih (A. sativum) dan daun bajakah (U. acida) untuk menguji efektivitas dalam membunuh larva A. aegypti instar III dalam tingkatan konsentrasi yang berbeda dan diharapkan dapat membantu dalam mengurangi angka persebaran demam berdarah dan kematian akibat penyakit Demam Berdarah Dengue yang setiap tahunnya menjadi masalah.

Alat yang digunakan dalam penelitian seperti autoclave, neraca analitik, sendok takar, erlenmeyer, batang bengaduk, gelas ukur / pipet ukur, mortar dan alue, blender, ovitrap, pisau, hot plate dan magnetic stier dan rotary evaporator.

Bahan yang digunakan dalam penelitian yaitu $A$. sativum dan daun $U$. acida, etanol dan aquades steril. 
Untuk mendapatkan jentik nyamuk $A$. aegypti diperlukan ovitrap. Setelah membuat ovitrap maka diletakkan pada lokasi yang terdapat nyamuk A. aegypti. Dari ovitrap yang digunakan didapatkan nymuka A. aegypti sebanyak 960 larva, akan tetapi sebelum larva nyamuk digunakan perlu diidentifikasi pada setiap larva agar larva nyamuk yang didapatkan benar-benar larva nyamuk $A$. aegypti.

Semua alat yang akan digunakan dalam penelitian diperlukan sterilisasi menggunakan autoclave dengan menggunakan tekanan tinggi berupa uap air panas bertekanan antara 1-2 atm ( \pm 15 lbs) selama 15-20 menit dengan suhu $121^{\circ} \mathrm{C}$, proses ini bertujuan untuk membunuh mikroorganisme yang ada pada alat gelas yang akan digunakan (Suprapti, 2020).

\section{Pembuatan Simplisia A. sativum dan Daun U. acida}

Dalam pembuatan simplisia dengan cara pengeringan tidak dilakukan dalam waktu yang lama agar tidak tumbuh kapang pada simplisia dan jika dilakukan pada suhu yang terlalu tinggi maka akan berakibat pada senyawa kimia yang terkandung di dalam simplisia (Widaryanto dan Nur, 2018).

\section{Pembuatan ekstrak etanol $A$. sativum dan $U$. acida}

A. sativum dan daun $U$. acida ditimbang menggunakan neraca analitik dan dihaluskan. Ekstrasi dilakukan dengan menggunakan metode maserasi, karena cara penyarian yang paling sederhana dan tidak memerlukan pemanasan sehingga menghindarkan rusaknya zat aktif dalam bahan yang digunakan. Pelarut yang digunakan adalah etanol. Proses maserasi dimulai dengan melarutkan $A$. sativum dan daun bajakah menggunakan pelarut etanol dengan perbandingan 1:10 (w/v). Dilarutkan sebanyak 10 bagian kemudian dituangkan dengan bagian 75 bagian etanol 96\% penyari. Ditutup dan dibiarkan selama 5 hari serta terlindungi dari cahaya sambil diaduk sesekali. Setelah 5 hari larutan disaring, ampas diperas dan dicuci dengan penyari secukupnya sampai diperoleh 100 bagian. Ekstrak yang diperoleh selanjutnya diuapkan dengan evaporator 
pada suhu $50^{\circ} \mathrm{C}$ kemudian dikeringkan dan ditimbang (Siahaan, 2020). Sebelum melaksanakan penelitian diperlukan uji pendahuluan untuk menentukan dan mengetahui kosentrasi larutan ekstrak $A$. sativum dan $U$. acida

yang akan digunakan nantinya dalam pengujian larvasida. Uji pendahuluan menggunakan larva nyamuk $A$. aegypti sebanyak 20 ekor dengan melakukan pengulangan sebanyak satu kali. Selanjutnya diberikan larutan ekstrak $A$. sativum dan $U$. acida dengan konsentrasi yang berbeda, jika dalam konsentrasi tersebut telah ada yang mencapai kematian larva nyamuk $A$. aegypti sebesar 100\% maka akan diambil konsentarsi dibawahnya.

\section{Pembuatan Larutan Stock}

Timbang 25 gr ekstrak $A$. sativum dan daun $U$. acida Selanjutnya buat konsentrasi dengan menggunakan rumus \%B/V sebanyak $50 \mathrm{~mL}$ untuk mendapatkan 50\% konsentrasi ekstrak A. sativum dan U. acida Pembuatan ekstrak larvasida menggunakan rumus pengenceran V1.M1 = V2.M2 dari konsentrasi larutan induk yang sudah di buat untuk mendapatkan larutan stock dengan konsentrasi $0 \% ; 0,6 \% ; 0,9 \% ; 1 \% ; 1,3 \% ; 1,5 \%$.

Tabel 1. Komposisi Ekstrak A. sativum

\begin{tabular}{|c|c|c|}
\hline \multirow{2}{*}{$\begin{array}{c}\text { Konsentrasi } \\
(\%)\end{array}$} & \multicolumn{2}{|c|}{ Komposisi } \\
\cline { 2 - 3 } & $\begin{array}{c}\text { Larutan Stok } \text { A. sativum } \mathrm{L} \\
(\mathrm{mL})\end{array}$ & $\begin{array}{c}\text { Aquades }(\mathrm{mL}) \\
(\text { Per } 50 \mathrm{~mL})\end{array}$ \\
\hline $0 \%$ & $0 \mathrm{~mL}$ & $50 \mathrm{~mL}$ \\
\hline $0,6 \%$ & $0,6 \mathrm{~mL}$ & $49,4 \mathrm{~mL}$ \\
\hline $0,9 \%$ & $0,9 \mathrm{~mL}$ & $49,1 \mathrm{~mL}$ \\
\hline $1 \%$ & $1 \mathrm{~mL}$ & $49 \mathrm{~mL}$ \\
\hline $1,3 \%$ & $1,3 \mathrm{~mL}$ & $48,7 \mathrm{~mL}$ \\
\hline $1,5 \%$ & $1,5 \mathrm{~mL}$ & $48,5 \mathrm{~mL}$ \\
\hline
\end{tabular}


Tabel 2. Komposisi Ekstrak U. acida

\begin{tabular}{|c|c|c|}
\hline \multirow{2}{*}{$\begin{array}{c}\text { Konsentrasi } \\
\text { (\%) }\end{array}$} & \multicolumn{2}{|c|}{ Komposisi } \\
\hline & $\begin{array}{c}\text { Larutan Stok U. acida } \\
(\mathrm{mL})\end{array}$ & $\begin{array}{c}\text { Aquades }(\mathrm{mL}) \\
\text { (Per } 50 \mathrm{~mL})\end{array}$ \\
\hline $0 \%$ & $0 \mathrm{~mL}$ & $50 \mathrm{~mL}$ \\
\hline $0,6 \%$ & $0,6 \mathrm{~mL}$ & $49,4 \mathrm{~mL}$ \\
\hline $0,9 \%$ & $0,9 \mathrm{~mL}$ & $49,1 \mathrm{~mL}$ \\
\hline $1 \%$ & $1 \mathrm{~mL}$ & $49 \mathrm{~mL}$ \\
\hline $1,3 \%$ & $1,3 \mathrm{~mL}$ & $48,7 \mathrm{~mL}$ \\
\hline $1,5 \%$ & $1,5 \mathrm{~mL}$ & $48,5 \mathrm{~mL}$ \\
\hline
\end{tabular}

Konsentrasi ekstrak dari A. sativum dan $U$. acida

Pembuatan konsentrasi ekstrak dari $A$. sativum dan $U$. acida yang akan digunakan sebagai larvasida masing masing sebesar 0\%;0,6\%;0,9\%; $1 \% ; 1,3 \%$; dan $1,5 \%$ yaitu dengan pengenceran dari larutan stock yang dibuat.

\section{Metode Pengukuran}

Nyamuk A. aegypti dimasukkan ke dalam wadah tertutup sebanyak 20 ekor untuk dilakukan uji larvasida ekstrak $A$. sativum dan $U$. acida Pemberian larvasida dengan konsentrasi yang berbeda dan dilakukan sebanyak 4 kali pengulangan selanjutnya diberikan kepada larva nyamuk. Pengamatan dilakukan dengan menghitung jumLah dan presentasi kematian nyamuk $A$. aegypti dalam waktu 24 jam pada pengamatan pada setiap jam ke $2 ; 4$; 6; 12; dan 24. Pengujian dilakukan dengan konsentrasi yang berbeda dan diberikan kode yang berbeda dan dilakukan 4 kali pengulangan.

\section{Metode Analisis Data}

Analisis data diolah dengan menggunakan uji normalitas Kolmogorov Smirnov, jika kurang dari 0,05 maka data berdistribusi tidak normal. Jika didapatkan data yang di bawah 0,05 menggunakan uji Kruskal wallis. Jika data berdistribusi normal maka uji yang dilakukan adalah One Way Anova. Untuk menjawab hipotesis kedua maka dilakukan dengan uji Mann Whitney jika data 
tidak normal, jika data berdistribus normal maka uji yang dilakukan adalah uji T-tes.

Dalam pelaksanaan penelitian pengujian larvasida $A$. sativum dengan larvasida U. acida dilaksanakan dalam waktu 24 jam dengan menggunakan jentik nyamuk $A$. aegypti sebanyak 20 ekor pada masing masing konsentrasi perlakuan dan diamati jumLah jentik nyamuk yang mati. JumLah kematian jentik nyamuk $A$. aegyti perlakuan dengan konsentrasi berbeda diperoleh data seperti pada Gambar 1 sebagai berikut:

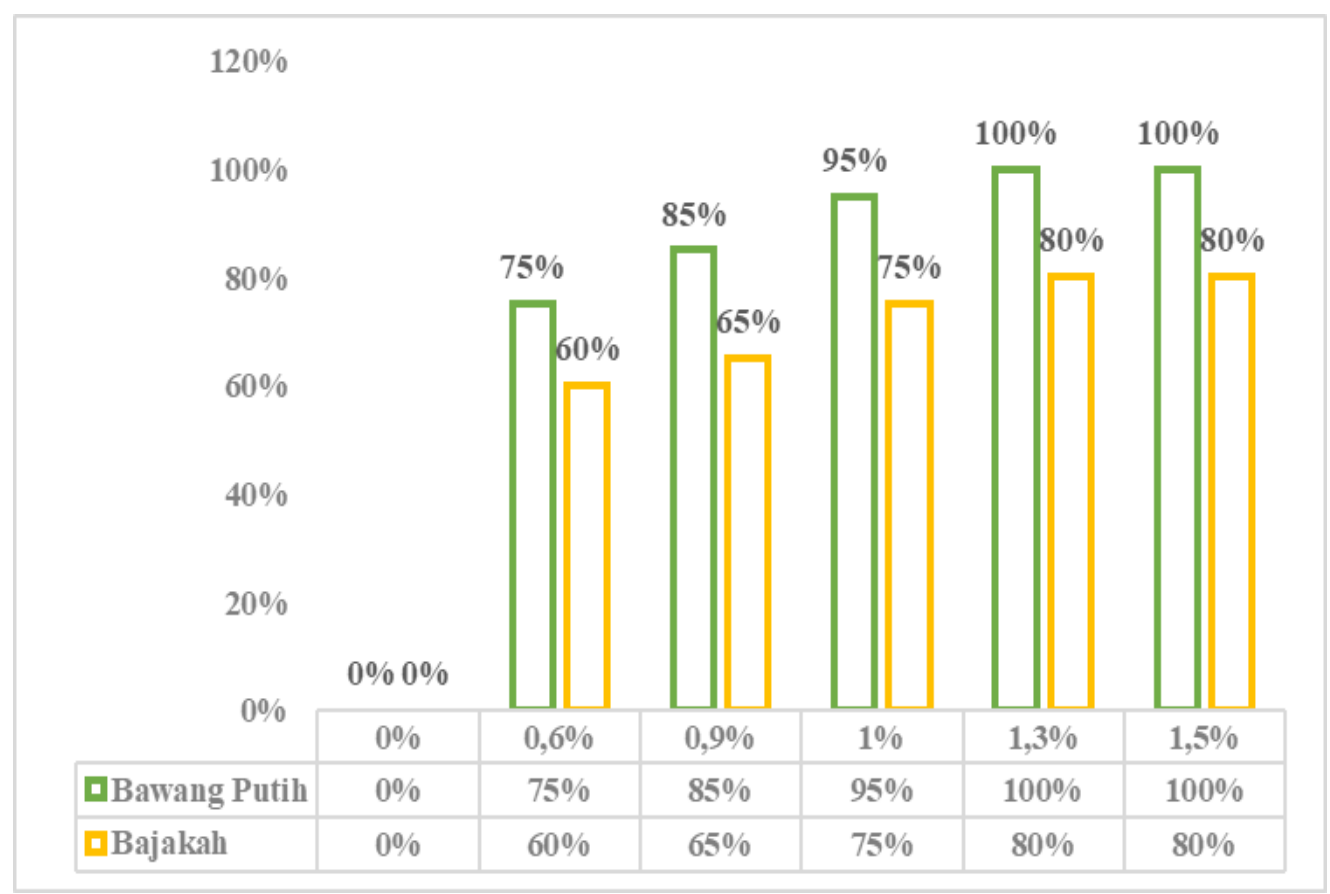

Gambar 1. Grafik Kematian Jentik A. aegypti Pada Setiap Konsentrasi Larutan

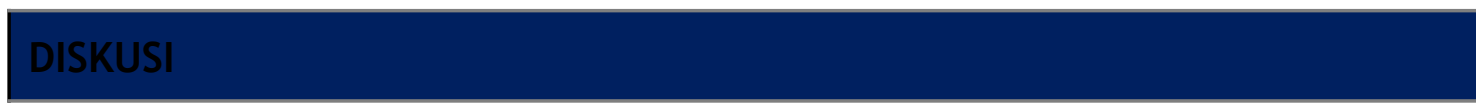

Penelitian ini dilakukan untuk mengetahui perbandingan efektivitas ekstrak $A$. sativum dengan bajakah sebagai larvasida vektor $A$. aegypti. Dalam penelitian ini menggunakan berbagai macam konsentrasi, hal ini bertujuan untuk mengetahui konsentrasi mana yang lebih efektif dalam membunuh jentik nyamuk $A$. aegypti. Konsentrasi yang digunakan sebanyak enam 
konsentrasi mulai dari konsentrasi $0 \% ; 0,6 \% ; 0,9 \% ; 1 \% ; 1,3 \% ; 1,5 \%$. Pemilihan konsentrasi tersebut didasarkan pada hasil uji pendahuluan yang telah dilaksanakan. Dari konsentrasi tersebut nantinya akan dibuat sebanyak $50 \mathrm{~mL}$ aquades dan dalam pengujian menggunakan jentik nyamuk sebanyak 20 ekor dan akan diulang sebanyak empat kali. Menggunakan jentik nyamuk sebanyak 20 ekor bertujuan untuk memenuhi standar WHO dalam penggunaan hewan uji dalam penelitian larvasida nyamuk dan pengulangan sebanyak 4 kali digunakan untuk memenuhi prosedur dalam uji analisa statistik (Pamungkas et al., 2017).

Menurut Nurhaifah dan Tri (2015) dalam pengamatan kematian jentik nyamuk $A$. aegypti dilakukan setelah diberikan larvasida, setelah itu dilakukan pengamatan setiap 2 jam; 4 jam; 6 jam; 12 jam; dan 24 jam. Waktu pengamatan digunakan untuk mengetahui kematian setiap jam yang telah ditentukan untuk mengetahui peningkatan kematian pada jentik nyamuk $A$. aegypti terhadap larvasida.

Berdasarkan hasil penelitinan dengan menggunakan larvasida bawang putih (A. sativum) menunjukkan bahwa pada perlakuan pemberian ekstrak $A$. sativum dengan konsentrasi yang berbeda yaitu $0 \% ; 0,6 \% ; 1 \% ; 1,3 \%$; dan $1,5 \%$ diperoleh jumLah kematian larva selama 24 jam masing-masing secara berurutan yaitu $0 \%$; 75\%; 85\%; 95\%; 100\%; dan 100\%.

Menunjukkan bahwa semakin tinggi konsentrasi ekstrak $A$. sativum yang diberikan maka memberikan efek mortalitas larva A. aegypti yang semakin tinggi, namun untuk konsentrasi 1,3\% dan 1,5\% memberikan efek yang sama yaitu 100\% larva mengalami kematian. Terjadinya peningkatan mortalitas larva nyamuk $A$. agypti karena terpapar dengan senyawa yang terkandung pada ekstrak $A$. sativum seperti senyawa alliin, alliinase, allisin, $\mathrm{S}$-allilsistein, dialil sulfida, alliil metil trisulfida yang merupakan senyawa organosulful. Sehingga pada setiap peningkatan jam maka jentik nyamuk sedikit demi sedikit akan mati karena terlalu lama terpapar senyawa dari ekstrak $A$. sativum. Berdasarkan hasil uji One Way Anova, untuk perlakuan pemberian ekstrak $A$. sativum memberikan hasil yang signifikan karena nilai $\mathrm{p}$ sebesar $0,049 \quad(<0,05)$. Hasil ini menunjukan bahwa terdapat perbedaan yang 
bermakna pada ekstrak $A$. sativum terhadap kematian jentik nyamuk $A$. agypti pada konsentrasi yang berbeda (Putri, 2017).

Berdasarkan hasi penelitinan dengan menggunakan larvasida daun bajakah (U. acida) menunjukkan bahwa pada perlakuan pemberian ekstrak $U$. acida dengan konsentrasi yang berbeda yaitu $0 \% ; 0,6 \% ; 1 \% ; 1,3 \%$ dan $1,5 \%$ diperoleh jumLah kematian jentik selama 24 jam masing-masing secara berurutan yaitu 0\%, 60\%, 65\%, 75\%, 80\% dan $80 \%$.

Hasil tersebut menunjukkan bahwa semakin tinggi konsentrasi yang diberikan maka semakin tinggi efektivitas daya bunuh pada jentik nyamuk $A$. aegypti. Terjadinya peningkatan mortalitas jentik nyamuk A. agypti karena terpapar dengan senyawa yang terkandung pada ekstrak $U$. acida seperti senyawa saponin, alkoloid, alliin, flovonoid yang merupakan senyawa organosulful. Sehingga pada setiap peningkatan jam maka jentik nyamuk sedikit demi sedikit akan mati karena terlalu lama terpapar senyawa dari ekstrak bajakah. Akan tetapi, terdapat perbedaan peningkatan mortalitas antara ekstrak bajakah dengan ekstrak $A$. sativum. Ekstrak $A$. sativum memiliki peningkatan mortalitas yang lebih tinggi dari pada ekstrak bajakah. Untuk mengetahui perbedaan kematian pada jentik nyamuk $A$. aegypti pada masing masing konsentrasi larvasida maka dapat menggunkan uji One Way Anova. Berdasarkan hasil uji One Way Anova, untuk perlakuan pemberian ekstrak daun $U$. acida tidak memberikan hasil yang signifikan karena nilai $\mathrm{p}$ sebesar 0,245 $(>0,05)$. Hasil ini menunjukan bahwa tidak terdapat perbedaan yang bermakna pada ekstrak daun bajakah terhadap kematian jentik nyamuk A. agypti pada konsentrasi yang berbeda (Putri, 2017).

Berdasarkan hasil penelitian diketahui bahwa larvasida $A$. sativum memiliki mortalitas yang lebih baik terhadap jentik nyamuk dibandingkan larvasida bajakah. Pada konsentrasi tertinggi yaitu 1,5\% untuk larvasida bajakah hanya memiliki mortalitas sebesar 80\%, sedangkan larvasida $A$. sativum memiliki mortalitas sebesar 100\%. Dan pada konsentrasi terendah yaitu $0,6 \%$ pada larvasida $U$. acida memiliki mortalitas sebesar $60 \%$ dan $A$. sativum memiliki mortalitas sebesar $75 \%$. 
Pada ekstrak $A$. sativum dan ekstrak $U$. acida diketahui memiliki kandungan senyawa yang bersifat organofosfat dimana senyawa ini dapat digunakan sebagai larvasida. Ekstrak A. sativum dan ekstrak $U$. acida memiliki senyawa seperti alliin dan flovoid. Sehingga didapatkan hasil dari kedua ekstrak $A$. sativum dan ekstrak $U$. acida sama-sama memiliki angka mortalitas yang tinggi pada jentik nyamuk $A$. aegypti (Putri, 2017).

Perbedaan jumlah kematian kedua larvasida, berkaitan dengan ketahanan setiap individual jentik terhadap konsentrasi yang diberikan. Semakin tinggi konsentrasi yang diberikan maka mortalitas akan meningkat, akan tetapi larvasida $A$. sativum memiliki angka mortalitas yang tinggi walaupun pengujian dilakukan dengan menggunakan konsentrasi yang sama. Pada larvasida A. sativum memiliki mortalitas tertinggi hingga $100 \%$ sedangkan pada larvaida $U$. acida hanya sampai $80 \%$. Adanya perbedaan mortalitas pada kedua larvasida bisa dipengaruhi oleh masing masing senyawa yang ada didalamnya. Seperti pada $A$. sativum terdapat senyawa alliin, alliinase, allisin, S-allilsistein, dialil sulfida, allil metil trisulfida dan pada U. acida terdapat senyawa saponin, alkoloid, alliin, flovoid (Saputera, 2018; Moulia dkk. 2018).

Dari kedua larvasida memiliki senyawa yang berfungsi sebagai larvasida, tetapi larvasida $A$. sativum lebih memiliki senyawa yang lebih kompleks dan banyak yang memberikan dampak yang besar. Seperti senyawa allicin yang merupakan senyawa yang toksik terhadap sel bakteri dansel parasit. Allicin berfungsi merusak membran sel jentik yang bernama sulfhidril $(\mathrm{SH})$ yang terdapat pada protein sehingga sel tersebut mengalami lisis sehingga menyebabkan kematian pada jentik nyamuk $A$. aegypti, tetapi pada $U$. acida terdapat senyawa flovonoid yang berfungsi sebagai larvasida. Senyawa flovonoid pada $U$. acida dapat berkerja sebagai inhibitor pernafasan yang dapat mengganggu metabolisme energi pada mitokondria yang menyebabkan terhambatnya sistem pengangkutan elektron. Adanya gangguan tersebut yeng dapat menyebabkan kematian pada jentik nyamuk $A$. aegypti, akan tetapi senyawa yang dimiliki oleh $A$. sativum lebih kuat dari pada senyawa yang 
dimiliki oleh $U$. acida sehingga kematian jentik nyamuk $A$. aegypti pada larvasida A. sativum lebih tinggi dibandingkan larvasida U. acida (Putri, 2017).

Pada uji analisa One Way Anova didapatkan nilai signifikansi dari larvasida $A$. sativum sebesar 0,049 dan pada $U$. acida 0,245 yang menunjukkan bahwa hasil dari ekstrak $A$. sativum memiliki nilai $p<0.05$ dan U. acida memiliki nilai $p<0.05 \mathrm{Hal}$ ini menunjukkan bahwa ekstrak $A$. sativum memiliki perbedaan yang bermakna terhadap kematian jentik nyamuk $A$. agypti pada konsentrasi yang berbeda sedangkan pada ekstrak daun $U$. acida tidak terdapat perbedaan yang bermakna terhadap kematian jentik nyamuk $A$. agypti pada konsentrasi yang berbeda. Sehingga dapat disimpulkan bahwa pada setiap konsentrasi ekstrak $A$. sativum dan ekstrak daun bajakah memiliki pengaruh terhadap kematian jentik nyamuk $A$. aegypti.

Hasil dari analisa T-tes didapatkan hasil sebesar 0,080 yang dapat simpulkan bahwa data tidak memiliki perbedaan yang signifikan antara larvasida A. sativum dan larvasida U. acida. Sehingga dapat diketahui bahwa ekstrak $A$. sativum dan ekstrak U. acida sama-sama efektif dalam membunuh jentik nyamuk $A$. aegypti.

Ekstrak bawang putih dan daun bajakah memiliki aktifitas larvasida pada berbagai konsentrasi dan tidak ditemukan adanya perbedaan aktifitas larvasida. Pengembangan larvasida alami dengan bahan alam bawang putih dan daun bajakah menjadi rekomendasi kami.

Ucapan terimakasih saya sampaikan kepada Dr. Ir. Luluk Sulistiono, M. Si Ketua Sekolah Tinggi Ilmu Kesehatan Borneo Cedekia Medika. Dalam penyusunan jurnal ini penulis banyak mendapat bimbingan dari berbagai pihak. Oleh karena itu, dengan tulus penulis mengucapkan terimakasih kepada orang tua dan teman-teman yang selalu memberikan semangat sehingga penulisan jurnal ini dapat selesai. Dan kepada dosen pembimbing 
saya ucapakan terimakasih banyak karena telah menuntun dan memebibing penulis hingga dapat menyelesaikan jurnal dengan baik.

Tidak ada konflik kepentingan dalam penyusunan jurnal ini.

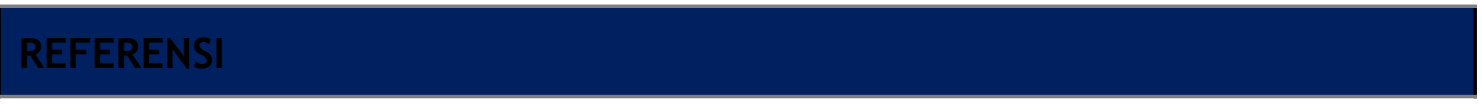

Aryati. (2017). Buku Ajar Demam Berdarah Dengue Edisi 2. Airlangga University Press: Surabaya. Diakses dari https://books.google.co.id/.

Dinas Kesehatan Kotawaringi Barat. 2020. Laporan DBD 2020. Dinas Kesehatan Kotawaringin Barat. Pangkalan Bun.

Dinata, Y. A. (2016). Rahasia Daya Tahan Hidup Nyamuk Demam Berdarah. Penerbit Deepublish. Yogyakarta. Diakses dari https: / / books.google.co.id/.

Indrayani, Y. A., dan Tri W. 2018. Situasi Penyakit Demam Berdarah di Indonesia Tahun 2017. Penerbit Info Datin. Jakarta.

Kemenkes RI. (2019). Daerah Siaga DBD. Diakses dari www.kemenkes.go.id/.

Moulia, M. N., Rizal S., Evi S. I., Harsi D. K., dan Nugraha E. S. (2018). Antimikroba Ekstrak Bawang Putih. Badan Penelitian dan Pengembangan Pertanian. Vol 27. Halaman 1. https://doi 10.33964/jp.v27i1.399

Nurhaifah, D. dan Tri W. S. (2015). Efektivitas Air Perasan Kulit Jeruk Manis Sebagai Larvasida Nyamu Aedes aegypti. Kesmas. Universitas Ahmad Dahlan. https://dx.doi.org/10.21109/kesmas.v9i3.56

Saputera, M. M. A. (2018). Uji Efektifitas Ekstrak Etanolik Batang Bajakah Tampala (Spatholobus littoralis Hassk.) terhadap Waktu Penyembuhan Luka. Jurnal Ilmiah Ibnu Sina. Akademi Farmasi ISFI Banjarmasin.

Saputera, M. M. A. (2018). Uji Efektifitas Ekstrak Etanolik Batang Bajakah Tampala (Spatholobus littoralis Hassk.) terhadap Waktu Penyembuhan Luka. Jurnal Ilmiah Ibnu Sina. Akademi Farmasi ISFI Banjarmasin. hhtps: / /doi.org/10.36387/jiis.v3i2.185.

Suprapti, L. (2020). Pedoman Pembuatan Media dan Reagensia Racik. Deepublish : Yogyakarta. Diakses dari https://books.google.co.id/.

Sembel, D. T. 2015. Toksikologi Lingkungan: Dampak Pemcemaran Dari Berbagai Bahan Kimia Dalam Kehidupan Sehari Hari. Penerbit CV Andi Offset. Yogyakarta. Diakses dari https://books.google.co.id/.

Susanty dan Fairus B. (2016). Perbandingan Metode Ekstraksi Maserasi dan Refluks Terhadap Kadar Fenolik Dari Ekstrak Tongkol Jagung (Zea mays L.). Konversi. Universitas Muhammadiyah Jakarta. https://doi.org/10.24853/konversi.5.8.87-92. 
Pamungkas, R. W., Neneng S. S., dan Arto Y. S. 2017. Perbandingan Efek Larvasida Minyak Atsiri Daun Cengkeh (Syzygium aromaticum L) Varietas Zanzibar dengan Temephos Terhadap Larva Nyamuk Aedes Aegypti. Pharm Sci Res. Universitas Padjadjaran. Bandung. https://doi.org/10.7454/psr.v3i3.3566.

Putri, R. H. (2017). Uji Efektivitas Larutan Bawang Putih (Allium sativum) Sebagai Larvasida Alami Pada Larva Aedes sp. di Kecamatan Kambu Kota Kendari. Politeknik Kesehatan Kendari. Tersedia dari Repository Poltekkes KDI (UMI No. P00341014031)

Widaryanto, E. dan Nur A. (2018). Perspektif Tanaman Obat Berkhasiat. UB Press : Malang. https://books.google.co.id. 